\title{
SEROPREVALENCE OF HEPATITIS B, HEPATITIS C AND HUMAN \\ IMMUNODEFICIENCYVIRUSES AMONGST DRUG USERS IN \\ 4 BORDER CITIES OF BANGLADESH
}

\author{
Rezaul Karim Kazal ${ }^{1}$, Md Sk Shahid Ullah², Afzalunnessa ${ }^{3}$, Hafiza Lona ${ }^{4}$, Shahjada Selirrv ${ }^{5}$
}

Drug addiction is a damaging national and social problem in Bangladesh affecting the economically productive groups. An estimated 1.7 million people are drug users in the country ${ }^{1}$.Drug users, especially injecting drug users (IDU) present a tremendous potential for transmission of blood borne viruses, including hepatitis $\mathrm{B}$ virus(HBV) ${ }^{2}$ hepatitis $\mathrm{C}$ virus $(\mathrm{HCV})^{3}$ and human immunodeficiency (HIV) virus ${ }^{4}$.They may exchange these viral infections among them through their needle/syringe sharing habits and may spread to uninfected low risk population through their high risk sexual behaviour or by donating blood professionally ${ }^{5,6}$.

In Bangladesh, several studies ${ }^{5,7,8}$ were done to understand the prevalence and mode of transmission, parenterally transmitted clinically important viral infections. About $7 \%-10 \%$ (9.1 to 13 million) population have hepatitis B and 2\%-3\% (2.6 to 3.9 million) of population have Hepatitis-C infection ${ }^{7,8,9}$. Most of the research works focusing drug users are concentrated in the capital city Dhaka and the vast peripheral zones especially border cities are yet to get priority. This study was, therefore, carried out to estimate the prevalence of $\mathrm{HBV}, \mathrm{HCV}$ and HIV infections among drug addicts in the 4 border cities (Rajshahi, Chapai Nababganj. Naogaon, Jaypurhat) situated in the western part of Bangladesh close to Indian Territory. The study was carried out between July 2007-January 2008. A total 300 drug users who were covered by a voluntary health education program, enrolled in this study among which 145 were injecting drug users and 155 were non-injecting drug user. After pretest counseling and informed consent $5 \mathrm{ml}$ venous blood was collected under aseptic precaution. HBV, HCV and HIV infections were detected by ELISA using commercially available kits and following manufacturer's instructions. Bangladesh. Seroprevalence of HBV, HCV and HIV and co-infection among various groups is given in the table.21 (7\%) of the 300 drug addicts were positive for HBsAg. The Seroprevalence of HBV is higher among the IDUs (7.5\% in IDUs vs $6.4 \%$ in NIDUs) although not significantly different. On the other hand, of the 300 drug user, 46 (15.3\%) were positive for anti HCV. 38 (26.2\%) among the IDUs and $8(5.1 \%)$ among the NIDUs ( $<<.001)$.i.e. the prevalence of $\mathrm{HCV}$ infection is significantly higher among the IDUs than the NIDUs indicating that hepatitis $\mathrm{C}$ virus is predominantly transmitted through parenteral route. However, some co-infection with HBV and HCV found in $7(2.3 \%)$ drug users, $4(2.7 \%)$ in IDUs and $3(1.9 \%)$ in NIUDs.

This result is consistent with other studies demonstrating that hepatitis $\mathrm{C}$ virus infection is an alarming problem among parenteral drug users ${ }^{7,8,9}$.

In the present study, anti HIV antibody was not detected in any of the cases whereas the prevalence of HIV in IDUs is $1-10 \%$ (average $7 \%$ ) in different zones of Dhaka city $^{9}$.

The territory of Bangladesh is mainly surrounded by Indian border. Cities near this zone harbour the channels of drug trafficking and menace of drug addiction.

Awareness, intervention and action plans on drug abuse and deadly infections mainly hit the capital city Dhaka. Comparing the result of our study with similar one based on Dhaka, it may be taken in concern that except HIV. the chances of HBV. HCV infection among the drug users in the remote areas are not slimmer.

Seroprevalence of HBV, HCV and HIV and co-infection among various groups is given in the table.

\begin{tabular}{|l|l|l|l|}
\hline Serology & IDUs n- 145 & NIDUs n- 155 & Total n-300 \\
\hline HBV & $11(7.5 \%)$ & $10(6.4 \%)$ & $21(7 . \%)$ \\
\hline HCV & $38(26.2 \%)$ & $8(5.1 \%)$ & $46(15.3 \%)$ \\
\hline HBV+HCV & $4(2.7 \%)$ & $3(1.9 \%)$ & $7(2.3 \%)$ \\
\hline HIV & 0 & 0 & 0 \\
\hline
\end{tabular}


1. Dr. Re/aul Karim Ka/al. Assisant Professor. Dcpt of Ohs \& Gynae. BSMMU.

2. Dr. Md. Sk Shahid Ullah. Assistant Professor. Dept of Microbiology. NICVD.

3. Dr.Afzalunnessa. Assistant Professor. Dept of Virology. BSMMU. Dhaka

4.Dr. Hafiza Lona. Lecturer. Dept of Biochemistry. Medical College for Women.

5. Dr. Shahjada Selim Assistant Reg. Dept of Medicine. ShSMC. Dhaka Corresponding Author: Dr. Rc/aul Karim Kazal.

Assistant Professor. Dept of Obs \& Gynae. BSMMU. Dhaka.

Among individuals infected with HBV infection. 5$10^{\circ} \mathrm{o}$ become carriers, and $4 \%$ suffer from chronic infection which may lead to chronic persistent or chronic active hepatitis, cirrhosis, or Hepatocellular Carcinoma 10. Infection with HCV has a high risk of progression to chronic liver disease ${ }^{11,12}$. About $50 \%$ of those infected with HCV develop chronic liver disease, and some of them progress to cirrhosis and even Hepatocellular carcinoma ${ }^{13}$. Given the fact that adequate programmes against substance abuse are lacking in Bangladesh, active preventive programmes focusing on educational campaigns among the youths against substance abuse should be undertaken. The fact that injection of illicit drugs using shared injection equipment is associated with infection of the liver by dangerous viruses, such as HCV and HBV, should be highlighted in the campaigns and peripheral zones should be given priority like central zone of Bangladesh. The high prevalence rate of HBV infection among the drug users also warrants hepatitis $B$ vaccination programme in the country.

\section{Reference:}

1. Bangladesh Narcotics Control Board. Role of mass media in control of drug abuse. Dhaka: Bangladesh Narcotics Control Board. Ministry of Home Affairs. Government of Bangladesh. 1999:15-20. (Occasional publication)

2. Levine OS, Vlahov D. Nelson K.E. Epidemiology of hepatitis B virus infections among injecting drug users: seroprevalence, risk factors and viral infections. Epidemiol Rev 1994: 16:418-36.
3. Esteban R. Epidemiology of hepatitis C virus infection. J Hepatol 1993: 17(Suppl3):S67-71.

4. Des Jarlais DC, Friedman SR, Choopanya K.VanichseniS, Ward TP. International epidemiology, of HIV and AIDS among injecting drug users. AIDS 1992:6:1053-68.

5. Shirin T. Ahmed T, Iqbal A, Islam M, Islam MM. Prevalence and risk factors of hepatitis B virus, hepatitis C virus, and human immunodeficiency virus infections among drug addicts in Bangladesh. J Health Popul Nutr 2000; 18:145-50.

6. Garfein RS. Vlahov D, Galai N. Doherty MC. NelsonKE. Viral infections in short-ter injection drug users: the prevalence of th hepatitis $C$. hepatitis B. human immunodeficiency, and human T-lymphotropie viruses. Am J Public Health 1996: 86:655-61.

7. Hsu HM. Wang YF, Lo SH. Sun HC. Yip KK. Chen JS et al. Hepatitis D virus infection among intravenous drug abusers in laiuan: analysis ot risk factors and liver function tests. J Med Virol 1990: 3 1:76-X 1.

8. Chen DS. Kuo GC. Sung JL, Lai MY. Shcu PJ. Chen P.I et al. Hepatitis $\mathrm{C}$ virus infection in an area hyperendemic for hepatitis $\mathrm{B}$ and chronic liver disease: the Taiwan experience. J Infect Dis 1990: 162:817-22.

9. Azim T. Rahman M. Alam MS. Chowdhury IA. Khan R. Re/a M. Rahman M. Chowdhury EI.Hanifuddin M, Rahman AS. Bangladesh moves from being a low-prevalence nation for HIV to one with $a$ concentrated epidemic in injecting drug users. Int J STD AIDS. 2008 May: 19(51:327-31.

10. Crawford JM. The liver and the biliary tract. In: Cotran RS. Kumar V. Robbins SL. Robbin's Pathological basis of disease. Philadelphia. MD: Saunders. 1995:831-96.

11. Alter MJ. Margolis HS. Krawezynki K. Judson FN. Mares A. Alexander WJ et al. The natural history of community-acquired hepatitis C in United States. N Engl J Med 1992: 327:1899-905.

12. Takahashi M. Yamada G. Miyamoto R. Doi T. Endo H. Tsuli T. Natural course of chronic hepatitis C. Am J Gastroenterol 1993; 88:240-3.

13. Gilliam JH. 3d. Geisinger KR. Richter JE. Primary hepatocellular carcinoma after non-A. non-B post transfusion hepatitis. Ann Inter Med 1984: 101:794-5. 